\title{
Nutrient characteristics assessment of two variants of okra (Abelmoschus esculentus L. Moench.) found in Anambra State, Nigeria
}

\author{
C.V. Ilodibia ${ }^{1}$, U.A. Achebe ${ }^{2}$ and C. Chiafor ${ }^{1 *}$ \\ ${ }^{1}$ Department of Botany, Nnamdi Azikiwe University, P.M.B 5025, Awka, Anambra State, NIGERIA \\ ${ }^{2}$ Department of Agricultural Education, Nwafor Orizu College of Education Nsugbe, Anambra State, NIGERIA \\ *Corresponding author's E-mail: chinyereokafor206@yahoo.com
}

\section{ARTICLE HISTORY}

Received: 15 September 2017

Revised received: 06 October 2017

Accepted: 10 November 2017

\section{Keywords}

Breeding improvement programme

Nutrient analysis

Nutritional values

Okra (Abelmoschus esculentus)

Variants of okra (Clemson spineless

and dwarf long green)

\begin{abstract}
Nutrient analysis was carried out on the leaves and fruits of two variants of okra (Abelmoschus esculentus) namely: Clemson spineless and dwarf long green varieties of $A$. esculentus commonly found in Anambra State, Nigeria, to determine their nutritional data with regards to protein, carbohydrate, moisture, ash contents, crude fibre and crude fat contents of $A$. esculentus using standard analytical techniques. Results were analyzed using analysis of variance. The leaves and fruits of the two varieties of $A$. esculentus investigated were found to contain the examined nutrient in varying compositions. Carbohydrate and moisture were higher in the fruits of both varieties of $A$. esculentus (Clemson spineless and dwarf long green) when compared to the leaves $(67.09 \pm 0.02$ and $11.45 \pm 0.07)$, respectively. Ash content, protein, crude fat and crude fibre of $A$. esculentus were higher in the leaves of both varieties when compared to the fruits $(9.10 \pm 0.14,21.55 \pm 0.21,5.33 \pm 0.18$ and $18.68 \pm 0.04)$ of $A$. esculentus, respectively. Protein and ash of A. esculentus were higher in the leaves of Clemson spineless when compared to dwarf long green. Crude fat and crude fibre were higher in the leaves of dwarf long green when compared to Clemson spineless. This study has demonstrated that these varieties (Clemson spineless and dwarf long green) of $A$. esculentus examined are power house of nutrients and can contribute significantly to human health. The study revealed that the leaves of $A$. esculentus are more nutritious than fruits. It is concluded from the present study that nutritional trials of both varieties (Clemson spineless and dwarf long green) of okra could be an additional aid to the breeding improvement programme of $A$. esculentus.
\end{abstract}

C2017 Agriculture and Environmental Science Academy

Citation of this article: Ilodibia, C.V., Achebe, U.A. and Chiafor, C. (2017). Nutrient characteristics assessment of two variants of okra (Abelmoschus esculentus L. Moench.) found in Anambra State, Nigeria. Archives of Agriculture and Environmental Science, 2(4): 298-300, DOI: $10.26832 / 24566632.2017 .020408$

\section{INTRODUCTION}

Okra (Abelmoschus esculentus), member of the family Malvaceae is a vegetable valued for many of its properties (Ilodibia et al., 2016a). It is widely cultivated for its edible green fruits, which are harvested when immature (Kumar, 2014; Ilodibia et al., 2016a). The pods of A. esculentus have a unique flavour and texture and release slimy mucilage on cooking, which can be used to thicken sauces and add smoothness to soups. Its seed may be roasted and ground to form caffeine - free substitute for coffee (Gemede et al., 2015). There are many lines of okra, each with some peculiar quantitative and qualitative characteristics. In the Eastern part of Nigeria, precisely Anambra, there are five varieties. They are; Green emerald, Dwarf long green, the local long pod variety, perkins spineless and Clemson spineless. The two varieties which are the focus of this study are the Clemson spineless and the dwarf long green. The Clemson spineless is long, narrow and do not possess spines; while the dwarf long green variety is shorter, greater in diameter and possess spines. The
Dwarf long green variety has a darker shade of green colour than the Clemson spineless (Van, 2005).

Good nutrition is fundamental for good health. It is the process by which we obtain food and use it for growth, keeping our bodies working properly and warding off diseases. In contrast, lack of nutrition or poor nutrition affects the body in a bad way and has been identified as the most significant factor contributing to the declining health status of indigenous people. It has been linked to heart disease, kidney damage and diabetes (Chopra et al., 2013; Kumar and Chopra, 2013). In children, it can stunt growth, tiredness and lead to poor concentration at school. Okra may be used in developing countries to mitigate malnutrition and alleviate food insecurity (Gemede et al., 2015). It is one of the vegetables that are nutritious, affordable and readily available in our area, of which consumed sufficiently could contribute significantly to human health. Determination of the nutrient composition of the available common varieties of Abelmoschus esculentus (Clemson spineless and the dwarf long green) in Anambra State, Nigeria was the aim of this study. 


\section{MATERIALS AND METHODS}

Study area, collection and identification of plant materials: The experiment was carried out at the Emery Biotechnology Laboratory, Ahia-Eke, situated in Umuahia, Abia State. The two varieties of Abelmoschus esculentus (Clemson spineless and the dwarf long green) used in this work were obtained between March and April 2016 and authenticated at the Agricultural development project (ADP), Kwata, Anambra state, Nigeria.

Materials and chemicals used for nutrient analysis: The following materials were used in the proximate analysis: Dessicator, muffle furnace, spectrometer, silica dish, Kjeldahl flask, funnel, Soxhlet apparatus, filter paper, thimble, electric oven, grinder, retort stand, test tube and test tube rack, crucible, weighing balance, petri dish. The chemicals used include: Tetrahydrosulphate (vi) acid, Boric acid indicator solution, Sodium hydroxide, Hydrochloric acid, Petroleum ether, Potassium hydroxide, Acetone, Phenolphthaline indicator, Ammonia, Dithezone solution, Carbon tetrachloride, Hydroquinoline, Phenonthroline, Vanado Molybidic acid, Selenium oxide.

Preparation of plant materials for nutrient analysis: Dried leaves and fruits of Clemson spineless and the dwarf long green of $A$. esculentus were ground into fine (100-mesh screen) powder. The ground samples were then examined for carbohydrate, ash content, protein content, crude fat content, crude fibre and moisture content of $A$. esculentus using the standard methods described by Association of Official Analytical Chemist (AOAC, 2005).

Statistical analysis: Data obtained was statistically analyzed using analysis of variance (ANOVA). The Duncan's multiple range tests was used to test the difference among treatments at $0.05 \%$ level. Results were presented in Mean \pm Standard Error.

\section{RESULTS AND DISCUSSION}

In the present study, the result revealed that the investigated nutrients of $A$. esculentus were present in all the parts of the $A$. esculentus varieties examined but in varied compositions (Table 1). Carbohydrate and moisture of A. esculentus were higher in the fruits of both varieties when compared to the leaves. Ash content, crude fat, crude fibre and protein of $A$. esculentus were higher in the leaves of both varieties when compared to the fruits. The findings are in agreement with
Kumar and Chopra (2013) who reported the higher contents of crude protein; crude fibre and carbohydrates in a high yield cultivar (IHR-31) of okra (Abelmoschus esculentus L.). During the present investigation, Protein and ash were higher in the leaves of Clemson spineless when compared to dwarf long green. Crude fat and crude fibre were higher in the leaves of dwarf long green when compared to Clemson spineless (Table 1). The leaves and fruits of the two varieties of $A$. esculentus investigated were found to contain the examined nutrient in varying compositions. Carbohydrate and moisture were higher in the fruits of both varieties (Clemson spineless and dwarf long green) of $A$. esculentus when compared to the leaves $(67.09 \pm 0.02$ and $11.45 \pm 0.07)$ of $A$. esculentus, respectively. Ash content, protein, crude fat and crude fibre were higher in the leaves of both varieties when compared to the fruits $(9.10 \pm 0.14,21.55 \pm 0.21,5.33 \pm 0.18$ and $18.68 \pm 0.04)$ of A. esculentus, respectively. Protein and ash were higher in the leaves of Clemson spineless when compared to dwarf long green. Crude fat and crude fibre of $A$. esculentus were higher in the leaves of dwarf long green when compared to Clemson spineless of $A$. esculentus. The high content of carbohydrate in the fruits of these varieties makes them a good source of energy. High contents of ash, fat, fibre and protein in the leaves of these varieties of $A$. esculentus make them good sources of these nutrients when compared to some vegetables like Celosia argentea, Telferia occidentalis (Ilodibia et al, 2016b). The leaves as a vegetable may be eaten as major food plants as supplementary food or cooked in combination with meat or fish, in stew, soup and various preparations (Ilodibia et al, 2014). Additionally, proteins are used for building and repairing of body tissues. Fibre aids and speeds up the excretion of waste and toxins from the body, preventing them from sitting in the bowel for too long, which could cause a buildup. High fibre also makes them good forage. Ash content of a plant based food is the function of mineral elements present. Moreover, dietary ash has proved helpful in establishing and maintaining acid-alkaline balance of the blood system (Hawkins, 1979; Ilodibia et al., 2014). Fats and oils help to regulate blood pressure and play vital role in the synthesis and repair of important cell parts (Dutta, 2003). The result is in line with work of (Ilodibia et al, 2016b and c) who reported similar results among the various parts of Celosia argentea and Gomphrena celosioides and (Rekha and Pushpa, 1988) that had same on the seed of Amaranthus species.

Table 1. Percent nutrient compositions of Clemson spineless and dwarf long green varieties of Okra (A. esculentus).

\begin{tabular}{|c|c|c|c|c|}
\hline \multirow{2}{*}{ Parameters } & \multicolumn{2}{|c|}{ Clemson spineless } & \multicolumn{2}{|c|}{ Dwarf long green } \\
\hline & Leaf & Fruit & Leaf & Fruit \\
\hline Moisture & $8.20 \pm 0.00^{\mathrm{a}}$ & $9.80 \pm 0.28^{\mathrm{b}}$ & $8.65 \pm 0.07^{\mathrm{a}}$ & $11.45 \pm 0.07^{\mathrm{c}}$ \\
\hline Ash & $9.10 \pm 0.14^{\mathrm{b}}$ & $2.73 \pm 0.17^{\mathrm{b}}$ & $8.65 \pm 0.07^{\mathrm{a}}$ & $2.13 \pm 0.11^{\mathrm{a}}$ \\
\hline $\mathrm{CH}_{2} \mathrm{O}$ & $39.45 \pm 0.12^{b}$ & $67.09 \pm 0.02^{\mathrm{c}}$ & $39.14 \pm 0.02^{\mathrm{a}}$ & $65.17 \pm 0.16^{\mathrm{a}}$ \\
\hline Crude fat & $4.10 \pm 0.14^{\mathrm{a}}$ & $1.20 \pm 0.00^{\mathrm{b}}$ & $5.33 \pm 0.18^{\mathrm{b}}$ & $2.10 \pm 0.00^{\mathrm{c}}$ \\
\hline Crude fibre & $17.60 \pm 0.28^{\mathrm{a}}$ & $6.40 \pm 0.00^{\mathrm{a}}$ & $18.68 \pm 0.04^{\mathrm{b}}$ & $7.30 \pm 0.14^{\mathrm{b}}$ \\
\hline Protein & $21.55 \pm 0.21^{\mathrm{b}}$ & $12.78 \pm 0.11^{\mathrm{b}}$ & $19.6 \pm 0.14^{\mathrm{a}}$ & $11.85 \pm 0.07^{\mathrm{a}}$ \\
\hline
\end{tabular}

Results are in Mean $\pm \mathrm{SD}$; the same letter in a column is not significantly different by Duncan's multiple range test at $(P<0.05)$.

\section{Conclusions}

The study has demonstrated that these varieties of $A$. esculentus examined are power house of nutrients. It revealed also that their leaves are more nutritious than fruits. The leaves and fruits of the two varieties of $A$. esculentus investigated were found to contain the examined nutrient in varying compositions. Carbohydrate and moisture of $A$. esculentus were higher in the fruits of both varieties (Clemson spineless and dwarf long green) when compared to the leaves $(67.09 \pm 0.02$ and $11.45 \pm 0.07)$ of $A$. esculentus, respectively. Ash content, protein, crude fat and crude fibre of $A$. esculentus were higher in the leaves of both varieties when compared to the fruits $(9.10 \pm 0.14,21.55 \pm 0.21,5.33 \pm 0.18$ and $18.68 \pm 0.04)$ of $A$. esculentus, respectively. Protein and ash were higher in the 
leaves of Clemson spineless when compared to dwarf long green. Crude fat and crude fibre of $A$. esculentus were higher in the leaves of dwarf long green when compared to Clemson spineless. Therefore, the present investigation concluded that the nutritional trials of both varieties (Clemson spineless and dwarf long green) of okra could be an additional aid to the breeding improvement programme of $A$. esculentus.

Open Access: This is open access article distributed under the terms of the Creative Commons Attribution License, which permits unrestricted use, distribution, and reproduction in any medium, provided the original author(s) and the source are credited.

\section{REFERENCES}

AOAC, Association of Official Analytical Chemists (2005). Official Methods of Analysis of the Association of Official Analytical Chemists International. Gaithersburg, Ontario Canada. pp: 2205 $-2314$.

Chopra, A.K., Srivastava, S., Kumar, V. and Pathak, C. (2013). Agro -potentiality of distillery effluent on soil and agronomical characteristics of Abelmoschus esculentus L. (Okra). Environmental Monitoring and Assessment, 185: 6635-6644, DOI 10.1007/ s10661-012-3052-8.

Dutta, A.C. (2003). Botany for Degree Students, Oxford University Press, New Delhi, India, pp: 301-588.

Gemede, H.F., Haki, G.D., Beyene, F, Woldegiorgis, A.Z. and Rakshit, S. K. (2015). Proximate, mineral and antinutrient compositions of indigenous Okra Pod Accessions: Implications for Mineral Bioavailability. Food Science and Nutrition, 4(2): 223-33.
Ilodibia, C.V., Igboabuchi, N.A. and Onwuachu, W.C. (2016a). Evaluation of vegetative and yield attributes of okra (Abelmoschus esculentus (L.) Moench) for adaptation in Anambra State, Nigeria. International Journal of Biological Research, 4(2): 318-320.

Ilodibia, C.V., Ewere, F.U., Akachukwu, E.E., Adimonyemma, RN, Igboabuchi, N. A. and Okeke, N.F. (2016b). Proximate composition, vitamin and anatomical studies on Gomphrena celosioides. Annual Research and Review in Biology, 10(3): 1-6.

Ilodibia, C.V., Chukwuka, C., Chukwuma, M.U., Akachukwu, E. E., Igboabuchi, N.A. and Adimonyemma, R.N. (2016c). Proximate composition, vitamin and anatomical studies on Celosia argente. British Biotechnology Journal, 15(4): 1-7.

Ilodibia, C.V., Ugwu, R.U., Okeke, C.U., Ezeabara, C.A., Okeke, N. F., Akachukwu, E.E. and Aziagba, B.O. (2014). Determination of proximate composition for various parts of two Dracaena species. International Journal of Botany, 10: 37-41.

Hawkins, H.F. (1979). Applied Nutrition Lee Foundation for Nutrition Research, Milwuke Wisconsin, pp: 217.

Kumar, V. (2014). Fertigation response of Abelmoschus esculentus L. (Okra) with sugar mill effluent in two different seasons. International Journal of Agricultural Science Research, 3(9): 164-180.

Kumar, V. and Chopra, A.K. (2013). Ferti-irrigational effect of paper mill effluent on agronomical characteristics of Abelmoschus esculentus L. (Okra). Pakistan Journal of Biological Sciences, 16(22): 1426-1437.

Rekha, S.S. and Pushpa, R.K. (1988). Composition of the seeds of some Amarathus species. Journal of Science of Food and Agriculture, 42(4): 325-331.

Van, B. (2005). Food Plants of the World: An Illustrated Guide. Timber Press, Inc., Portland, Oregon. pp: 32-52. 